\title{
The Need for Liquidity and the Capital Structure of Swedish Banks Following
}

\section{the Financial Crisis}

\author{
Victor Nilsson ${ }^{\mathrm{a}}$, Joakim Nordström ${ }^{\mathrm{b}}$, Krister Bredmar ${ }^{\mathrm{c}^{*}}$ \\ ${ }^{a, b, c}$ School of Business, Economics and Law, University of Gothenburg, Sweden
}

\begin{abstract}
Banks had a large part in the developments taking place in the years after the outbreak of the crisis in 2007, as many banks had an excessively low capital base, involving too much risk in its businesses. In this study, the largest four banks in Sweden have been investigated. The financial crisis affected the banks differently, depending on the markets of expansion. Excessive risk-taking has been found, where one bank expanded aggressively into new markets and did not appreciate the risks on these new markets. CEO compensation and risk seeking boards are factors that might have caused such behaviour. All of the banks have made noticeable changes to their capital structure, increasing it annually, accompanied by a risk-reduction movement in their assets to improve the stability in most of the banks. The new regulation's focus on both quality and quantity is in accordance with the views that are expressed in the framework. The banks have altered their goals to levels several per cent above the regulations, in contrast to before the crisis when they were often as close as possible. The impact of the new liquidity regulations has been limited, as the banks continue to work with their internal measures. The banks have all changed their view of capital ratio and liquidity, where many of the banks have doubled the amount of these posts and now find these measures to be both beneficial and a way to gain trust and stability.
\end{abstract}

Keywords: Basel Accords; Basel Committee; Liquidity; Capital structure; Financial crisis; Management Control

JEL Code: G12, G15

\section{(C) 2014 Published by SSBFNET}

\section{Introduction}

The financial crisis of 2007-2008 had a great impact on banks through the mortgage backed securities which had undergone excessive securitization. These assets made the banks' capital position even weaker than it already was, as the assets did not live up to the returns that had been promised. The credit-rating agencies did not investigate these assets, and many banks and other institutions, as well as companies, trusted these overly positively rated mortgage bonds, which gave them a big hole in their balance sheets when the truth was revealed. The banking sector had a serious crisis closing in, and it was not ready for a test of financial strength during that time. Pre-crisis leveraging was very common, which meant that at the start of the financial crisis the banks did not have a capital base close to stable levels. Instead, the capital base was reduced to the lowest amount possible for the sake of increasing the leverage and to make the bank more attractive for investments.

\footnotetext{
${ }^{*}$ Corresponding author. Krister Bredmar
} 
Many banks operated to a high-risk involved strategy, perhaps sometimes not considered as overly risky. But as the financial crisis hit the industry, these risks were made visible. The following developments lead up to the bankruptcy and crises of many banks, first in America, with the ripples in the market caused by this development reaching the whole international market in a few months' time. This lead to a discussion of how the banks manage themselves, and handle their financing and capital structure, which will be the focus of this paper. How banks managed their businesses will be investigated, which in many cases meant a very high debt-equity ratio and a low liquidity buffer on the limits of the banks internal system. This development caused many to speak for another harsh regulation of the banking market (Dewatripont, Rochet, \& Tirole, 2010). The balance sheet did not receive the attention it needed, and many risks were overlooked in the years leading up to the financial crisis. This caused a turbulence not seen for a very long time, forcing the various countries to stabilise their banks with their taxpayers' money, something that has caused a severe distrust of the banking sector.

While this extreme high risk-high return way of banking has changed, it is still important to measure the actions taken and if this has actually reduced the risk and converted the liquidity and capital structure of the banking business. The banking industry has received much of attention after the financial crisis, with many new regulatory changes, and the pressure to stay liquid and have a stable capital ratio is more important than ever. This movement has been brought up partly because the banking sector got part of the blame for the financial crisis, with for example the bankruptcy of Lehman Brothers. The bankruptcy augmented the on-going crisis, pulling the world economy further into recession. This study will question whether banks have taken an active position in improving the stability after 2007 and 2008, trying to change the earlier risk-filled environment. Other recent developments in the banking business to improve banking, either from regulatory institutions or states, will be discussed. If this approach is applicable, did the changes come from within the bank or did pressure from institutions and perhaps even the governments ensuring the safety of the banks in the various countries cause these changes?

The effects that the financial crisis has had on the view of capital structure within the banks, as well as how their financial strategy evolved after the changes in the banking sector, will be investigated. The process of the possible change of view concerning liquidity and capital structure from 2007 until now in 2012 will be investigated. If there is a visible change, what changes has been made through these years. In addition to this, whether the current outlook on liquidity and capital structure has changed to a more risk-averse way of conducting business will be included in the paper. Furthermore, the challenges that the banks have faced after the crisis, and whether they have achieved the goals which they might have set up to handle the pressure on the banking business as a whole will be looked into. The aim of this study is to increase our understanding of what changes in the liquidity and capital structure of banks would mean for the stability and trust in the banking business and what in reality have been done after an event such as international financial crisis. 


\section{Frame of References}

The Basel Committee was formed in 1974 by Governors of central banks. The purpose of the committee is to set standards for the regulation of banks as well as to improve the cooperation of supervising banking. The committee does not have any legal authority, so it relies on its members to set aside their national interests and work together to enforce the standards of the committee (Charter, 2013).

The Basel Capital Accord (also referred to as Basel I) was introduced in 1988. The Accord stated that the banks were to hold a minimum capital of $8 \%$ of its assets. Basel II was proposed in 1999 and after being revised it was taken in use in 2004. This accord expanded on the first to contain three pillars. The first was an expansion of the capital requirements of Basel I. The second was an improved role for supervisors, and the third was an attempt to improve the market discipline by increasing transparency. After the financial crisis in 2008 the committee began developing another update to the Accords. The content will be phased in gradually and is set to be completely in use by 2019 (Basel Committee on Banking Supervision, 2013).

In Basel III the capital requirement has been adjusted to deal with the lack of high quality capital during the crisis. Therefore, in the new Accords the emphasis is on the highest quality of capital, common equity, also known as core equity. The total capital can be split up into tier 1 and tier 2, with the former consisting of common equity and additional tier 1 capital. Three ratio restrictions are outlined in Basel III: A global regulatory framework for more resilient banks and banking systems (Basel Committee on Banking Supervision, 2011, p. 12):

- $\quad$ Common Equity Tier 1 must be at least $4.5 \%$ of risk-weighted assets at all times

- $\quad$ Tier 1 Capital must be at least $6.0 \%$ of risk-weighted assets at all times

- $\quad$ Total Capital (Tier 1 Capital plus Tier 2 Capital) must be at least $8.0 \%$ of risk-weighted assets at all times

Another issue brought to attention during the crisis was the leverage that had been built up in the banks. This was done even though the risk based capital ratios were strong. As a solution Basel III includes a leverage ratio to complement the capital requirements. The ratio will be tested from 2013 till 2017, with a minimum of $3 \%$ tier 1 leverage ratio (Basel Committee on Banking Supervision, 2011).

\subsection{Banking Regulation}

Many countries bailed out financial institutions that were deemed too important to fail. Lilico (2012) argues that to avoid this scenario in the future the regulation needs to focus on reforms that increases the reliability of governments to not bail out banks. In the reforms that have taken place so far, five key areas can be identified. In addition the reforms already in action, Lilico insists that there is need for further development.

One problem is the view that fractional reserve banking is without risk. The author argues that there is indeed risk and that the depositors' interest is a compensation for the risk they take. However, it is problematic that there is no viable option besides having all one's money physically. One possible solution is for banks to offer a "storage deposit", which would be $100 \%$ backed up by government bonds. Since these deposits would be less risky the interest rate 
would be significantly lower than regular deposits. Further, even though there is risk, the risk of losing the whole deposit is limited. The recovery rate for deposit during the 1930s bank runs were above $80 \%$. These recoveries, however, can be lengthy procedures. Hence, the issue is not if the depositors will lose their capital but the liquidity issues during the process of regaining the capital. A solution to this problem is a Deposit Access Fund, owned by the government. This enables withdrawals from banks in administration as usual, up to a limited percentage. If the bank is liquidated and its assets cover the deposits the depositor is unaffected, otherwise it will be owned to the state as a tax liability. By offering a less risky alternative there will be less sympathy to losses and the public will be less likely to favour a bail out (Lilico, 2012).

One criticism of Basel III is that there is no penalty for portfolio concentration in Pillar 1. By failing to diversify their portfolio banks will increase their risk. The suggested solution to this is setting a benchmark for a diversified portfolio where the minimum leverage ratio is in effect. If a bank deviates from this benchmark they require more capital the further they stray from it. Another criticism is towards the risk-weighting approach. Banks can use complete markets to shift risks and thus their leverage can be expanded. There is also scepticism of the view that the quality of capital was more important in the crisis than quantity. Though a higher quality of capital will be helpful in the reduction of risk, there needs to be a higher level of the required capital (Blundell-Wignall \& Atkinson, 2010).

A discussion on how banks react to the regulation and other research on the subject can be found in the article by Van Hoose (2007). The author brings a more critical view of the at the time available literature and interprets the effects Basel II has had on banks in correlation with the literature on capital regulation. The regulation of Basel I and II, and the effects that these have brought to the banking business, where the literature often interprets these regulations as negative effects on the risk-taking of banks. Van Hoose finds that even though there are cases where positive effects of using capital requirements can be found, which may result in reduction of risk-taking in banks, further this could possibly lead to a reduced amount of lending and higher rates. The discussion proceeds to whether the capital requirement regulation has the desired effect or not, as the results found in literature on the subject changes, depending on what is emphasised within the paper. In the case of banks as portfolio managers it supports the idea of capital regulation, even though there is no way of telling if it truly makes the banking system safer in terms of overall risk. Regulation should be more focused on safety instead of a more complex capital requirement, a most accurate view as this article was written at the end of 2006 a year ahead of the financial crisis.

\subsection{Global Financial Crisis}

The deregulation of banks that allows them to participate in non-traditional banking has been accused of being a major part in the failure of many banks during the financial crisis. DeYoung \& Torna (2013) investigates how income from these activities affected US commercial banks during the financial crisis. By making the distinction between three types of activities, they get a more in depth look at what role deregulation played in the problems banks faced during the crisis. They found that banks that engaged in high-risk activities, such as investment banking and venture capital, also took more risks in their more traditional banking activities. Banks performing other activities such as insurance 
sales showed to have a lower probability of failing. The distinction of these types of activities can be taken into consideration when forming supervision of the banks, making it more efficient.

The structure of banks can be a factor in how well they are able to cope with crises. The trend among banks is toward a more local presence. Banks can be categorized into two classes, international and multinational, by how their business in foreign markets is conducted. International banks have a strong base in their home country and rely heavily on cross-border business. In contrast multinational banks tend to let their foreign offices or branches operate more autonomously. Banks can also be categorized by centralization or decentralization, where multinational banks can be put in either category and international banks are mostly centralized. During the crisis multinational and decentralized banks are assessed to have been more stable, in part due to the stability of local assets compared to cross-border liabilities. The upcoming LCR regulations with a local liquidity requirement may be a factor that drives more banks towards a decentralized structure (McCauley, McGuire, \& von Peter, 2012).

Barr (2012) analyses the Dodd-Frank reform that was implemented in the US during 2010 as a response to the financial crisis and what needs to be done both in the US and internationally moving forward. He argues that the required capital needs to improve in both quantity and quality, and for an improved supervision of Systemically Important Financial Institutions (SIFIs). The calculation of risk-weighted assets is problematic as calculation differs between countries as well as between financial firms. Unless these are homogenized this may affect competition of global banks. To be able to supervise SIFIs, cooperation across countries needs to improve. A way of achieving this is by pre-crisis planning where regulators of the different nations agree to share information and agree resolution plans. Today this is problematic due to confidentiality and other constraints.

\subsection{Management}

The relation between bank board structure and bank risk-taking in an agency theory perspective is useful concerning the financial crisis of 2007-2008. In a study on this subject, the results shows that risk-taking in banks is positively related to strong boards, with small boards and less restrictive boards as definition of strong boards (Pathan, 2009). These result supports the idea that a strong board will further the interest of the shareholders, as they prefer a higher amount of risk. In terms of CEO power to risk-taking the relationship is negatively related, this may depend on the relatively low fixed salary, the un-diversifiable wealth that they may have as compensation and as such, CEOs may seek a lower risk. The authors conclude that since bank board structure is an important factor of bank risk-taking, regulators should give this more attention.

Ownership by management and board-members impacts profitability in three different types of European banks, traditional, non-traditional and diversified. The results of a study included in this paper support earlier studies concluding that management and board ownership improves profitability. Where a positive effect in non-traditional banks exists for management ownership, there is the same effect on board ownership in traditional banks. The author concludes that management ownership is important for banks that are non-transparent, where it is difficult for 
outsiders to monitor them. Board ownership has an incentive to monitor banks due to a safety net and as such there is not the same need for management ownership (Westman, 2011).

Whether there is a correlation between compensation structure and the excessive risk-taking that may have contributed to the financial crisis effects is something that has been brought up many times in media. That fact has given compensation structure a lot of attention due to public outrage at the compensation found in some banks. A paper about this well-known subject finds that while there is some slight evidence to this, the CEO compensation was not the cause of the financial crisis and does not explain bank risk-taking (Acrey, McCumber, \& Nguyen, 2011). However, Swedish banks have been working with a continuing adjustment to new European regulations concerning rewards systems and risk taking, after the financial crisis (Jaha, Nawrocki, \& Bredmar, 2013).

Sallie Krawcheck (2012) brings up four ideas to further the responsible risk-taking and a more sustainable banking industry. One is to compensate executives with more varied options and bank debt, the second one is to stay away from the set amount for dividends and use a percentage of the bank's earnings instead, thirdly for determining bank performance, net interest income importance should be lessened and customer satisfaction and other non-qualitative metrics should be given more of the focus. The final idea propagates that focus should not be at the part of the business that is performing worse, but on those that are using the most capital, even though they may be the most profitable. The first idea brings up that while stock compensation can be effective as an incentive, it brings about too much risk. An occurrence that could be seen as some of the members with the highest stock compensation had high positions in the banks at the centre of the financial crisis.

\subsection{Liquidity}

During the financial crisis banks struggled despite having sufficient capital structure, due to a lack of liquidity. Therefore, in Basel III liquidity was added as one of the main components of the regulations, in the form of Liquidity Coverage Ratio (LCR). The ratios purpose is to secure that banks can remain liquid for a stress period of 30 days. To be able to withstand the 30 day period the bank need adequate levels of High Quality Liquid Assets (HQLA). The HQLA is compared to a calculated net total cash outflows and is required to match or exceed these outflows. During crises the banks are expected to liquidate these assets and thus temporarily falling below $100 \%$ LCR is in order. The start of these new rules will be 1 January 2015 with a minimum of $60 \%$ LCR. The required ratio will be increased annually by $10 \%$ culminating in 2019 with $100 \%$ (Trade Finance, 2012). In Sweden the regulations were applied on January 1, 2013 with a requirement of $100 \%$ LCR (Finansinspektionen, 2012).

The LCR has received criticism from several authors. Valladares (2013) argues that by trying to make it fit too many countries, cultures and political systems the content gets too thin. He argues that the change to a less strict implementation of LCR lessens the benefit of the regulation. The widening of the assets included in the LCR numerator is also criticized. It is questioned how liquid these assets really are when the crisis hits. The author also highlights the risk that the regulations will keep being watered down and further delayed as the banks keep arguing against them. Another criticism of the LCR is that when the banks are required to hold more liquidity it may affect 
their returns. A possible side effect is taking higher risks in other areas to compensate. Another possible issue is the one-size-fits-all rules, as the quality of sovereign bonds varies and may in fact be risky assets (Blundell-Wignall \& Atkinson, 2010).

It is not only a lack of liquidity that can be troublesome. It has also been shown that during the financial crisis banks hoarded liquidity as a safety move when the liquidity risk began to rise. Bank lending decreased during the crisis and $25 \%$ of this reduction can be explained by precautionary liquidity hoarding. The effect of this hoarding can be a disrupted interbank market (Berrospide, 2013). Banks may also hoard liquidity to be prepared to take advantage if other banks fail and the opportunity to purchase assets for fire-sale prices. The bailout policy will have consequences here, if the government is willing to assist failing banks the motivation to hold more liquidity gets weaker (Acharya, Shin, \& Yorulmazer, 2011).

Ratnovski (2013) argues for two key components for dealing with liquidity risk and the connection between them. The first one is a liquidity buffer, which in case of a small shock will work as perfect cover. For large shocks the importance of transparency increases as a way of securing refinancing. Uncertainty over solvency played a crucial part in recent liquidity crises. By being transparent the banks can lower the uncertainty and thereby make refinancing available. Without adequate transparency bank can be subject to liquidity risk even though they are solvent. These two factors work as complements and by managing them well the banks stand a good chance of dealing with crises. While regulation of a liquidity buffer is rather straightforward, transparency is more difficult and harder to verify. The implementations of liquidity requirements can decrease transparency and as a result risk will be increased. Consequently, Ratnovski argues that the liquidity requirement needs to be supplemented, for example by better corporate governance.

Globalization is another factor to consider when forming rules and regulations for the banking industry. Global banks are less susceptible to changes in monetary policy compared to banks operating within more limited areas. With more banks being global, investigating liquidity shocks on a domestic level might be less significant. The shocks will be transmitted internationally to a larger extent than previously, due to the global banks' ability to transfer funds between their foreign branches. This calls for a better collaboration between nations as individual country policies have limited effect (Cetorelli \& Goldberg, 2012).

\subsection{Capital Structure}

Credit risk exposure is of utmost importance for a bank, and how it manages its loans is one way of managing such risk. Cebenoyan \& Strahan (2004) test how interactions with the loan sales market affect the capital structure of banks. They find evidence for that banks that are active and relatively more effective in trading credit risks on the loan sales market, both selling and buying, have less assets deemed at risk. However, this is not the only difference caused by this as the banks that are more active also reduce their held capital, compared to banks that are only active on either the buying or selling side in the loan market. These banks tend to have the highest levels of risky loans in comparison to the less active banks on the loan market. Larger bank size and affiliation with Bank Holding Companies correlates 
with a smaller capital base. These results come from numbers of banks during the period 1988-1994 and these will only be used as a reference point to how business was conducted before the crisis.

Bank strategy concerning capital ratio and what banks use to adjust their capital ratio is an area of research that can further the capital structure discussion and secondly why banks choose certain setups in their capital structures. A paper on this subject discusses a few questions concerning capital structure ratio and the management associated with it (Memmel \& Raupach, 2010). The starting question is for investigating however banks are using capital ratio targets, and how and in what way they respond to changes in market climate and shocks. The second question brings up which characteristics that identify banks that use such adjustments and lastly probability of failing to meet capital regulation targets and what it depends on. The authors found that mostly, banks use a certain target that they wish to achieve. To achieve these targets they use either the liability side or buying or selling assets, with a more effective change for the former and a faster change for the latter. They also found that banks with a higher target tend to have a higher asset risk or higher adjustment speed, for the sake of meeting the regulatory targets.

Why financial institutions have such a high leverage compared to the non-financial companies is a question brought up by Inderst \& Mueller (2008). They contribute to this subject with reasons to why banks and other financial institutions should have such a high leverage, and even above their level of received deposits. The authors argue for that leverage gives positive effects, up to a certain level. Their findings show that instead of only making banks to take excessive risks they show that leverage is necessary to be able to give first-best incentive for risk-taking. The reason is to provide the banks with the possibility to make new risky loans through the optimal capital structure developed in the paper.

A combined paper by Allen, Fulghieri and Mehran (2011) brings up results from papers on different subjects in the banking sector. The first subject is bank capital, where the study found that there is an optimal capital structure for every bank. In the paper they find that concerning bank capital, value is increasing in capital, however this is in the cross-section of banks. There also seems that a positive effect can be observed between total bank value and bank capital. Another subject concerns the financial crisis and contagion, on how one bank's failure impacts other banks' performance. The authors found that higher exposure between banks leads to higher deposit withdrawals, with the exposure as the reason behind this and not other factors correlated to withdrawals. The linkage between the banks also furthers the spreading of shocks during crises. Weaker banks with less capital, smaller sizes suffer more from contagion from other banks. As a last result banks with higher exposure may find a reduction in loan growth and profitability, while some banks have unaffected profitability because an increased amount of deposits due to the withdrawals.

Whether bank capital structure has any effect at all, and if it does how it should be adjusted, is a question brought up in a paper by Diamond and Rajan (2000). With the main points being what role capital has for a bank, giving the result that capital helps in a bank's liquidity and credit, while adding to the stability of the bank. The optimal capital structure for a bank in this paper comes down to three effects, increased capital increases the rent absorbed by the 
banker, while increasing the buffer against shocks and changes the amount that can be extracted from borrowers. While this article contains many interesting parts, it develops a model for further research.

A different opinion on the financial crisis of 2007-2008 can be found in a paper by Akhigbe, Madura and Marciniak (2012). This view contains how the investor perspective of bank risk in financial and market data affected their actions during the crisis, and how bank managers and regulators of banks can prevent the same kind of event with huge shocks to bank stock prices, accompanied by the lack of availability of new capital when needed. Something they found was that banks with more capital, a larger "cushion", got a more negative impact during the crisis, with the reason being that assets held by these banks had a lower quality especially during a financial crisis. The higher risk found brought about a huge shock when frightened investors left the banks expecting the unknown assets being of lower quality. The investors conclude this from the fact that a bank that keeps a higher level of capital during the crisis most likely has a higher level of risk in its assets. The result being that even though a greater capital pool could have been an efficient help against the effects of the crisis, it simply is not enough to handle the market panic that broke out. The ending discussion brings up a more long-term solution for executive compensation, and with this keep banks from having a higher asset risk together with the higher capital in case of possible losses.

A study investigates the effects capital has on survival and market shares for banks, with banking and market crises and during more stabilized situations. They find that for small banks, during any type of the given situations, capital gives improved survival rate and increased market shares (Berger \& Bouwman, 2013). This is not the case with medium to large banks (small banks with gross total assets of up to $\$ 1$ billion, medium exceeding $\$ 1$ billion up to $\$ 3$ billion and large banks exceeding $\$ 3$ billion), that only gains something from a higher capital ratio during financial crises. Small banks also have a higher profitability with a higher amount of capital, as well as other benefits such as: Better growth in non-core funding, on-balance-sheet relationship loans and off-balance-sheet guarantees. The relationship between the small banks and larger banks holds true here as well, where the larger sized banks only have these benefits during the crises. They discuss the possibility that to larger banks, size has an impact on their economic strength, while smaller banks need a larger amount of capital to achieve the same strength in such terms.

What will cause certain effects on capital structure is a subject brought forth by Harding, Liang and Ross (2013). The authors use a few characteristics that banks inherit to investigate these effects on capital, the first being that banks can issue federally insured debt. Secondly, suffer the threat of being placed in receivership from regulators and thirdly that they manage financial assets instead of physical, lowering the bankruptcy costs. The paper findings include that banks with deposit insurance, a minimum capital ratio and a bank franchise value choose to have excess capital higher than the regulatory minimum. Which they conclude does not mean that the regulation is without effects as banks would still choose a corner solution if there were no minimum capital requirement. The threat of liquidation also contributes to banks taking up a capital cushion, which cannot completely be done the same way with regulation as they cannot investigate all the risks concerning that single bank. 


\subsection{Theoretical Outline}

In the literature concerning the management of banks, the main discussion is risk-taking, both from the bank itself and its CEO and board. The studies reviewed on this subject bring up various structures for banks as well as the correlation between compensation of CEOs and excessive risk-taking. There is no consensus between the papers, as there is research that argues that CEO compensation was one of the causes of the financial crisis due to the excessive risktaking, and others that state that there is no such connection and CEO might even seek lower risk.

The studies reviewed about capital structure all relate to the topic of different aspects that affect the capital ratio of the banks. One subject that is common within the papers is the optimal capital structure for financial institutions, i.e. banks. This is a subject that would ease some of the worries concerning the safety and stability of the banking sector if a solution was found. Different results can be found in the papers reviewed, however there is no aligned opinion concerning the optimal capital structure of banks. The effects of the financial crisis and what would cause banks to choose various capital ratios is discussed and there is no conclusion in the available literature to whatever ratio that would be most successful.

The search for literature on liquidity revealed several critical views, primarily with LCR being questioned for its attempt to fit too many countries and cultures. It also showed signs that banks not only suffered from a lack of liquidity, but also tendencies of holding on to extra amounts when the crisis hit. The need to improve the banks liquidity is connected with the need for an improved regulation. Several suggestions for improvement were found, including rules for diversified portfolios and increasing the level of required capital.

The research on the financial crisis showed that the banks' structure and activities affected the ability of the bank to cope with the environment changes. Banks' with investment banking departments and other high-risk activities tended to take more risks in their traditional banking. Banks with a decentralised structure were more likely to remain stable during the crisis.

\section{Methodology}

The study was done with a qualitative method, to fit with the aim of the study of improving understanding of the changes the banks have made. This study uses both a semi-structured form of interviews and analysis of financial reports. The annual reports often address the shareholders and thus needs to maintain a positive outlook, even when the company is experiencing rough times. This affected the analysis of the CEO letters, although since the analysis also contains measures that have been standardised through the Basel Accords (See figure 1-3), some part of this positive presentation have been avoided. One advantage of this method is the availability of the documents at the banks' websites.

The ideal profession of the interviewee was deemed to be Head of Investor Relations, as their unique position allows the insight and overview of the bank required for this study. The necessary information and data was collected from the financial reports and statements of the four largest banks in Sweden, starting before the crisis 2007 and leading up to the present situation 2012. As a supplement to this data from the financial reports, interviews were conducted with 
head of investor relations of Handelsbanken, Nordea, SEB and Swedbank. Literature concerning the financial crisis of 2007-2008 was used to accompany these interviews, covering the development during the period and the banks' financial reports showing their view of the situation.

To gather information from the annual reports the CEO letters were read, as well as the sections that regarded strategy and financial targets. The reports were also searched for a set of predetermined key ratios and figures, or comparable if these were not available. There might be a slight impact on what set of capital and liquidity ratios the banks have chosen to focus on, as they can differ according to what the banks has deemed most important. The interviews were the compliment for the financial reports, improving the insight to the banks and the developments during the financial crisis.

The used measures are based on regulation by the Basel Committee, although they have changed because of the turbulent financial situation. Through the different Accords, Basel I, II and III, the regulation has changed with each update of the framework. This has caused several problems as this study investigates change over time. The different methods of calculation for the key-measures complicate comparison, both between banks and over time.

\section{Results \& Discussion}

The revisions of the Basel regulations are a common topic for the banks to discuss. Though Sweden have implemented a stricter set of rules than the revised Basel III, as well as an earlier implementation, the banks all express the expectation for the rules to be adapted to the new rules eventually. One change that can be noticed compared to before the crisis is the targets the banks set in comparison to the regulations. Before the crisis the targets were set close to the requirements of the regulations, whereas now they can be several percent above this limit. What the respondents said coincides with what Lilico (2012) writes on the aspect of risk. Handelsbanken discussed their profile as a bank with a low risk-profile where they steer away from business that may have a potentially high compensation, but where the risk is too high, and have done so since before the crisis. They also discussed the danger of having a bonus based reward system for a bank, as it can lead to excessive risk taking, especially if the banks are certain that the government will bail them out in case of emergency. On the contrary, Swedbank stated that leading up to the crisis the development perhaps included taking too much risk. Therefore their work has been focused on reducing the bank's risk.

The regulations have both increased the focus on quality and quantity by not only increasing the requirement, but also putting more emphasis on the core tier 1 capital, the highest quality capital. This fits with Blundell-Wignall \& Atkinsons (2010) argument that focus cannot only be on quality, although both are needed. The banks claim to have a diversified liquidity portfolio.

\subsection{Global Financial Crisis}

The impact of the crisis varied greatly between the banks. One major factor for how deeply the banks were affected was the involvement in markets outside the Nordic countries. Swedbank's and SEB's heavy involvement in the Baltic countries, where they had expanded quickly and had become market leaders, led too much of their decreased 
profitability during the crisis. Nordea also operates in the Baltic States but to a lesser extent, only representing about 3 $\%$, of their business. So the region's downturn did not have as much overall effect on the bank. Two of the banks, Handelsbanken and Swedbank, express a decentralised structure with autonomous branches. The difference in stability for the banks during the crisis does not concur with the conclusion of McCauley et al. (2012), where decentralised banks coped better during the crisis. It is important however to note that the crisis affected some of the banks' home markets differently, so the comparison is somewhat flawed.

Barr's (2010) argument for an increase in both quantity and quality of required capital matches the development seen in all Swedish banks, as the equity increase for the banks have been between $42-64 \%$, as shown below in figure 1. The problems with the risk-weighted assets are something that several of the interviewees have agreed with. The lack of standardisation is critiqued, as the banks' own models are used. Therefore comparison between the banks can get unfair. Another suggestion from Barr that is in line with what banks' expression is the need for better cooperation between countries. Since all of the banks have home markets outside of the Nordic countries, this is of great importance.

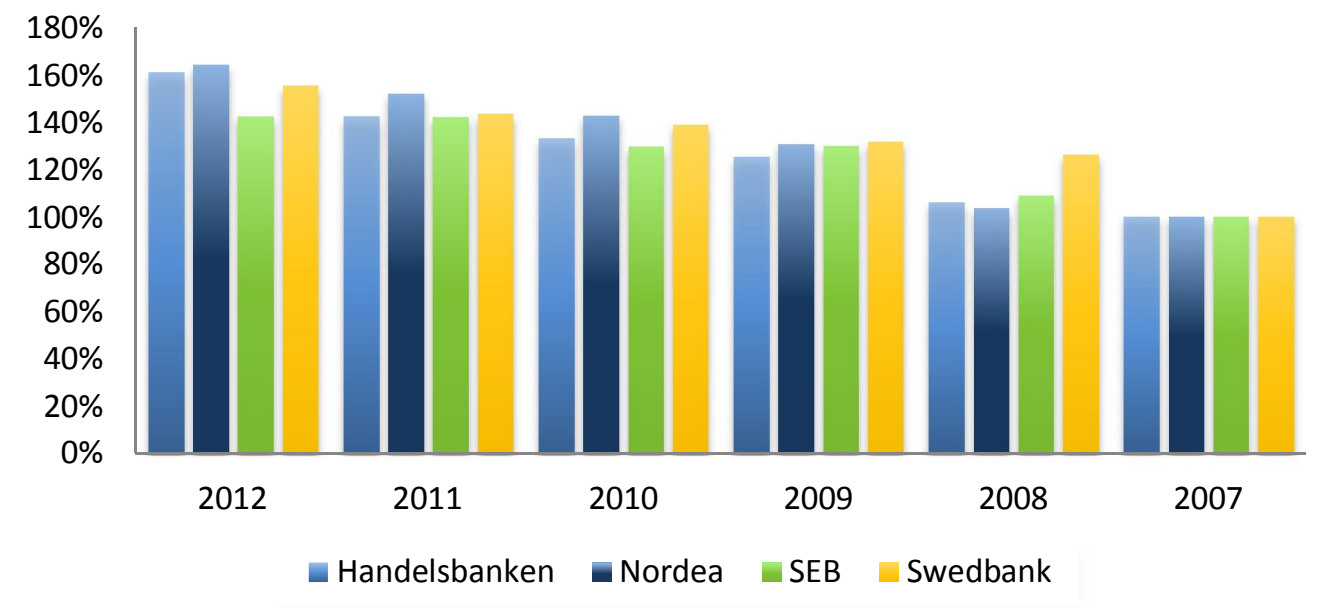

Figure 1 Equity, Index

\subsection{Management}

The risk-taking of banks is something that received much of attention after the financial crisis, involving both boards and CEO's to take the blame for the excessive risks in the banks' leveraging and assets. For Swedbank, there were some factors that may have been caused by this kind of risk-taking, with a large investment in markets that are insecure about how their system works. The bank withdrew from Russia and Ukraine, as lending in this area involved a risk, which was not taken into consideration during the time of investment. A strong board could cause this kind of behaviour, as a stronger board might increase the shareholders' risk appetite (Pathan, 2009). Now, Swedbank has moved on to transparency as one of its goals, which will further improve the image of the bank. In the pre-crisis years, management ownership might have improved the risk-taking in the bank, and in the present board, ownership might 
be more suitable as management ownership has become less important after the transparency movement. This is because of the incentive for the board to monitor its own bank (Westman, 2011).

The correlation between CEO compensation and excessive risk-taking is something that has been widely discussed and within the Swedish banks there are many differences (Jaha et.al, 2013). While board risk-taking might have moved the bank into the new regions, it could be a CEO decision moving the bank as well. There are divided opinions on this subject, while some argue that CEO compensation did not cause the risk-taking that started the financial crisis (Acrey et. al, 2010), others provides facts that many of the crisis bringing banks had highly compensated CEO's (Krawcheck, 2012). On the other hand, Handelsbanken does not use incentives at all, completely moving away from this structure and the danger of excessive risk-taking present in most banks.

\subsection{Liquidity}

All the banks stated that they had increased their liquidity after the crisis. This strengthening started before the new regulations with LCR was introduced. Thus, the ratios have not affected the banks operations in any major ways. The only bank that stated that they had been directly affected was SEB, but they also stated that they had already begun to strengthen the liquidity before the ratio was introduced. The banks continue to work with different internal methods to measure their liquidity, such as Swedbank's survival horizon.

Increased transparency is something that Swedbank in particular expressed as a key factor moving forward, both in the interview and in the annual reports. This fits well with Ratnovski's (2013) views on the importance of transparency in dealing with major crises. Swedbank was the bank experiencing most turbulence so building trust and securing refinancing was vital to their business. This is also important as the bank had to change its strategy and also had to change the perceptions as a bank that took too much risk before the crisis. The implementation of the stricter rules in Sweden counters some of the criticism from Valladares (2013), though the banks are expecting changes to the regulations.

That globalization played an important role in the effect on the different banks. In accordance to Cetorelli \& Goldberg (2012), the need for more collaboration, can be showed by the impact the Baltic countries had on the Swedish banks. Even though the Swedish market stayed relatively stable, the problems the Baltic countries experienced hit the Swedish banks hard and affected their whole business. It is in the interest for all the involved countries and the banks to make sure that this situation cannot occur again, but if it does, the nations need to cooperate to deal with it in the best possible way. One criticism that the banks have expressed is regarding LCR. The problem is how the different assets are valued as liquid, resulting in what was described as a race to invest in the central banks. This can be related to the problem of LCR being too general to fit all the affected countries (Valladares, 2013; Blundell-Wignall \& Atkinson, 2010). It is difficult to reflect on the fact that sovereign bonds of different countries will be of different quality, as this would demand a great deal of extra work. 


\subsection{Capital Structure}

All of the banks have made significant changes to their capital structure, moving to increase their stability and to stay above the limit of the new regulation that will come with Basel III. Most of the banks have moved up to levels much higher than the capital requirement that will be issued with the new regulation, according to the banks' own strategy. Now in their 2012 annual reports, Handelsbanken and Swedbank have a tier 1 capital ratio at about $20 \%$, moving into very safe area in terms of capital adequacy, as seen in figure 2. It is often noted that banks with deposit insurance, minimum capital ratio and a bank franchise value tend to have a higher capital ratio than the regulatory requirement (Harding et al, 2013), something that can be seen in most of the banks in Sweden. The regulatory minimum will move up to $12 \%$ in 2015, something that all four banks have reached and gone past. Nordea has the lowest tier 1 capital ratio at $14.3 \%$, which also involved an increase of state-insured papers to fulfil the requirements of the capital requirement.

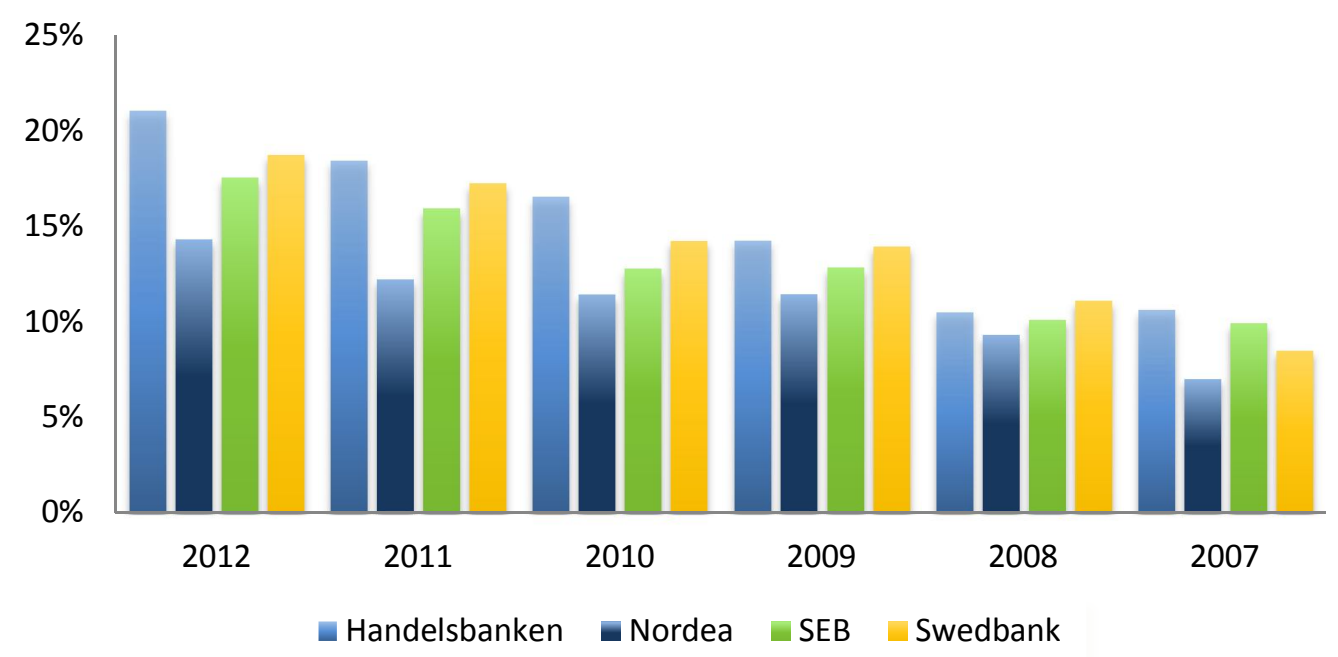

Figure 2 Capital Ratio Development

The movement of an increased capital ratio of the banks is opposite to before the crisis, when leveraging was a very common practice for banks worldwide. This involved the attempt to get as high leverage as possible, while having the lowest amount of capital possible. This way of banking was brought up in most of the interviews with the bank representatives, giving it further reliability. Before the crisis, some of the literature used argues that a higher leverage was important to achieve first-best incentive for risk-taking, instead of just making banks take excessive risks (Inderst \& Mueller, 2008). As can be seen from the outcome of the crisis, leveraging did cause serious problems, and many banks have changed direction to a more stable capital structure and leverage, because of the complications with the risk-taking associated with the low capital ratio. The regulation from the Basel Accords also has a role in the change of capital ratios, with more strict rules to avoid this kind of excessive risk-taking. 
All of the banks were, and still are, active on the loan sales market, which is something that brought a lower capital ratio because of the relatively more effective way of managing their credit risks (Cebenoyan \& Strahan, 2004). This, together with the size of the banks, might have been one of the reasons for a lower capital base, but the banks that were able to handle their risks experienced a much less uncertain position in the financial crisis. There are many other factors to this choice, as many banks use a capital ratio target or goal for their business (Memmel \& Raupach, 2010). During most of the years investigated, all of the banks had capital ratio targets, concerning mostly tier 1 capital, the choice of this type of capital measure depends on the regulatory minimum.

During the financial crisis, there was another problem that involved some of the Swedish banks. Swedbank had noticeable trouble with the impact of riskier assets on the balance sheet as the cause of this problem. Literature on the subject associates a higher capital base with a higher asset risk (Akhigbe et al, 2012). This theory most likely affects smaller banks to a greater extent, as their market position does not allow them the same freedom to capital and liquidity, something that is an advantage of the larger banks (Berger \& Bouwman, 2013). However, during the financial crisis, markets were shut down and availability of resources was extremely limited, which meant that even larger banks were being shut out. As in the case of Swedbank, assistance from the Swedish National Debt Office was received to handle the problems during the financial crisis. As can be seen in figure 3, the amount of risk-weighted assets was heavily reduced for Swedbank. Handelsbanken also reduced their amount of such assets, gaining a more stable position with less risk. This movement can be seen as one of the steps to achieve a higher trust from their clients, mainly Swedbank, that were hit hard during the financial crisis and needed this change of risk orientation.

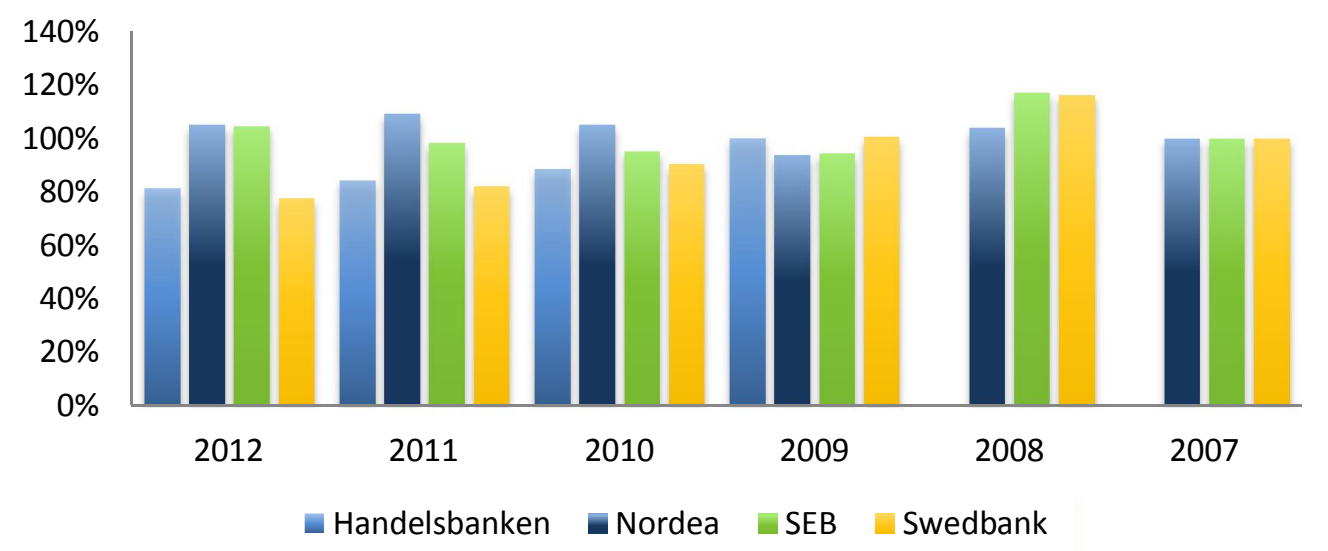

Figure 3 Risk-weighted Assets, Index

\section{Conclusion}

The financial crisis forced major changes in the Swedish banking business. The most noticeable change caused by the crisis is the difference in the view and the ratio of capital structure. The bank with the lowest percentage change has close to doubled their tier 1 capital ratio, with the three other banks at double the amount of tier 1 capital in 2007. The view of capital structure has changed from the leveraging of the years before the crisis, to that a stronger capital base is not only necessary but also beneficial for the reason of gaining trust from clients and lowering borrowing costs. The 
consequences of the crisis can be found in the year of 2009, bringing down results and negative profits for most banks, reducing the return on equity for all banks and bringing about the movement towards a higher capital ratio. Three of the banks performed a rights issue and for Swedbank a second rights issue was required, owing to the problems that had surfaced in the Baltic countries as well as Russia and Ukraine. The only bank that remained stable and did not perform a rights issue was Handelsbanken, which continued their way of banking throughout the crisis.

Two critical adjustments, caused by the financial crisis, were made within the banks. The most significant restructuring has been done in Swedbank, which has moved from aggressive expansion to a structure that emphasises transparency and sustainability. These changes originate in the uncertain financial situation and the future it could possibly trigger. The need for a more sustainable way of banking was evident, as for Swedbank's part their expansion into the new markets had proved to be too risky. This forced the bank to change its entire structure to keep it from collapsing, making a movement to start regaining the trust of its clients. All of the banks have altered their financial goals because of the financial crisis and its effects, a very distinguished movement of strategic goals was perceived in Nordea, in the form of four initiatives. The four banks have made changes to their liquidity and capital structure, due to the focus on return on equity as a financial goal. Return on equity has been used more because of the lowered leverage in the banking sector. It has become important as a result of the fact that banks have less leverage to achieve the yield that was normal for the banking sector pre-crisis, thus making other factors more important than just leverage.

The regulatory changes have not resulted in any major differences for the banks investigated. While monitoring the regulators, the four banks moved according to their own policies and strategies. The regulation for capital structure has been modified to a higher capital ratio, which banks acknowledge but they have taken steps to remain ahead of this regulation. The new regulation is stricter, however. The banks have realised that they need to have a stronger capital base and liquidity to manage the market changes that has evolved from the financial crisis.

A direct consequence of the financial crisis is the change in the view of liquidity for all of the four banks. This change can be observed in their increase of the liquidity reserves and the quality of these reserves. However the comparability between the banks is questionable. This uncertainty comes from the absence of any standardised liquidity measures between the banks, which have resulted in all four banks using their own internal liquidity measures to a greater extent. Handelsbanken and Nordea have reported liquidity buffers double the pre-crisis levels. This progress can be recognised throughout the industry, with close to excessive increases of liquidity buffers to sustain the banks in the case of a new financial crisis.

\section{References}

Acharya, V., Shin, H., \& Yorulmazer, T. (2011). Crisis resolution and bank liquidity. Review of Financial Studies, 24(6), 2166-2205. 
Acrey, J., McCumber, W., \& Nguyen, T. (2011). CEO incentives and bank risk. Journal of Economics and Business, 63(5), 456-471.

Akhigbe, A., Madura, J., \& Marciniak, M. (2012). Bank capital and exposure to the financial crisis. Journal of Economics and Business, 64(5), 377-392.

Allen, F., Fulghieri, P., \& Mehran, H. (2011). The value of bank capital and the structure of the banking industry. Review of Financial Studies, 24(4), 971-982.

Barr, M. (2012). The financial crisis and the path of reform. Yale Journal on Regulation, 29(1), 91-119.

Basel Committee on Banking Supervision. (2011). Basel III: A global regulatory framework for more resilient banks and banking systems. Retrieved 2013-04-23, 2013, from http://www.bis.org/publ/bcbs189.pdf

Basel Committee on Banking Supervision. (2013). A brief history of the Basel Committee. Basel: Bank for International Settlements.

Berger, A. N., \& Bouwman, C. H. (2013). How does capital affect bank performance during financial crises? Journal of Financial Economics, 109(1), 146-176.

Berrospide, J. (2013). Bank liquidity hoarding and the financial crisis: an empirical evaluation. Working paper series: Federal Reserve Bank of Atlanta(21), 1-41.

Blundell-Wignall, A., \& Atkinson, P. (2010). Thinking beyond Basel III: Necessary solutions for capital and liquidity. OECD Journal: Financial Market Trends(1), 9-33.

Cebenoyan, S., \& Strahan, P. E. (2004). Risk management, capital structure and lending at banks. Journal of Banking \& Finance, 28(1), 19-43.

Cetorelli, N., \& Goldberg, L. (2012). Banking globalization and monetary transmission. Journal of Finance, 67(5), 1811-1843.

Charter. (2013). Basel committee on banking supervision. Basel: Bank of International Settlements.

Dewatripont, M., Rochet, J.-C., \& Tirole, J. (2010). Balancing the banks: global lessons from the financial crisis. Princeton: Princeton University Press.

DeYoung, R., \& Torna, G. (2013). Nontraditional banking activities and bank failures during the financial crisis. Journal of Financial Intermediation, 22(3), 397-421.

Diamond, D., \& Rajan, R. (2000). A theory of bank capital. Journal of Finance, 55(6), 2431-2465.

Finansinspektionen. (2012). Finansinspektionens föreskrifter om krav på likviditetstäckningsgrad och rapportering av likvida tillgångar och kassaflöden. Stockholm: Finansinspektionens författningssamling.

Harding, J., Liang, X., \& Ross, S. (2013). Bank capital requirements, captial structure and regulation. Journal of Financial Services Research, 43(2), 127-148.

Inderst, R., \& Mueller, H. M. (2008). Bank capital structure and credit decisions. Journal of Financial Intermediation, 17(3), 295-314.

Jaha, V., Nawrocki, M., \& Bredmar, K. (2013). Changing the game - financial crisis, the Swedish Financial Supervisory Authority and reward systems in Swedish banks. International Journal of FInance and Accounting, 2(1), 24-29. 
Krawcheck, S. (2012). Four ways to fix banks. Harvard Business Reivew, 90(6), 106-111.

Lilico, A. (2012). How is banking regulation changing, and how could it be better? Economic Affairs, 32(3), 6-10.

McCauley, R., McGuire, P., \& von Peter, G. (2012). After the global financial crisis: From international to multinational banking? Journal of Economics and Business, 64(1), 7-23.

Memmel, C., \& Raupach, P. (2010). How do banks adjust their capital ratios? Journal of Financial Intermediation, 19(4), 509-528.

Pathan, S. (2009). CEO power and bank risk-taking. Journal of Banking \& Finance, 33(7), 1340-1350.

Ratnovski, L. (2013). Liquidity and transparency in bank risk management. Journal of Financial Intermediation, 22(3), 422-439.

Trade Finance. (2012). Basel III: Liquidity coverage ratio revised. Trade Finance, 15, 116.

Valladares, M. (2013). New Basel III liquidity rules ineffectual. American Banker, 178(4), 8.

VanHoose, D. (2007). Theories of bank behavior under capital regulation. Journal of Banking \& Finance, 31(12), 3680-3697.

Westman, H. (2011). The impact of management and board ownership on profitability in banks with different strategies. Journal of Banking \& Finance, 35(12), 3300-3318. 